Omelicheva, Mariya Y. Reference Group Perspective on State Behavior: A Case Study of Estonia's Counterterrorism Policies, Europe Asia Studies, 61(3): 483-504, 2009. Publisher's Official Version: <http://dx.doi.org/10.1080/09668130902753317>.

Open Access Version: <http://kuscholarworks.ku.edu/dspace/>.

[This document contains the author's accepted manuscript. For the publisher's version, see the link in the header of this document.]

\title{
Reference Group Perspective on State Behaviour: A Case Study of Estonia's Counterterrorism Policies
}

\author{
Mariya Y. Omelicheva
}

\author{
Paper citation: \\ Omelicheva, Mariya Y. Reference Group Perspective on State Behavior: A Case Study of \\ Estonia's Counterterrorism Policies, Europe Asia Studies, 61(3): 483-504, 2009.
}

\begin{abstract}
:
For over a decade Estonia has been untouched by terrorist violence. However, notwithstanding the lack of a viable terrorist threat, the Estonian government adopted extensive counterterrorism measures. What explains the scope of Estonia's counterterrorism measures? The main proposition of this article is that the content of states' counterterrorism policies is shaped by the types of responses adopted by their reference groups. The evidence examined in the study demonstrates that Estonia's primary reference groups, NATO and the EU, have influenced the republic's counterterrorism programme. An unattractive target to terrorists, Estonia adopted broad counterterrorism responses to defend indivisible Euro-Atlantic security and to protect democratic values that terrorists attempt to destroy.
\end{abstract}




\title{
Reference Group Perspective on State Behaviour: A Case Study of Estonia's Counterterrorism Policies MARIYA Y. OMELICHEVA
}

\begin{abstract}
For over a decade Estonia has been untouched by terrorist violence. However, notwithstanding the lack of a viable terrorist threat, the Estonian government adopted extensive counterterrorism measures. What explains the scope of Estonia's counterterrorism measures? The main proposition of this article is that the content of states' counterterrorism policies is shaped by the types of responses adopted by their reference groups. The evidence examined in the study demonstrates that Estonia's primary reference groups, NATO and the EU, have influenced the republic's counterterrorism programme. An unattractive target to terrorists, Estonia adopted broad counterterrorism responses to defend indivisible Euro-Atlantic security and to protect democratic values that terrorists attempt to destroy.
\end{abstract}

TERRORISM HAS NEVER POSED A SIGNIFICANT SECURITY THREAT TO ESTONIA. The last acts with essential elements of terrorism were registered there in the early 1990s. During that time, the republic experienced a turbulent transitional period after regaining its independence from the Soviet Union. Since then, no crimes that could be qualified as terrorism according to the republic's legislation have been attempted or carried out in the country. However, despite a widespread belief that Estonia is an unattractive target for terrorists, the republic has adopted extensive counterterrorism measures encompassing different areas of public and foreign policy. The Estonian government has noticeably increased defence and security spending. The Estonian Security Police has upgraded its counterterrorism capabilities and activated surveillance. The number of soldiers that Estonia has committed to international peacekeeping and counterterrorism operations has been among the highest per capita in the world. Notwithstanding the overwhelming public 
Omelicheva, Mariya Y. Reference Group Perspective on State Behavior: A Case Study of Estonia's Counterterrorism Policies, Europe Asia Studies, 61(3): 483-504, 2009. Publisher's Official Version: <http://dx.doi.org/10.1080/09668130902753317>. Open Access Version: <http://kuscholarworks.ku.edu/dspace/>.

Europe Asia Studies, 61(3): 483-504, 2009.

disapproval of Estonia's military engagement in Iraq, the government sent a 43-member regiment to Baghdad, a notable size for an army that averages 3,800 servicemen in peacetime. In the war against terrorism, Estonia has contributed millions of US dollars, thereby straining the republican budget. What explains the scope of Estonia's counterterrorism activities and operations?

\section{Rival explanations of state behaviour}

Political science is replete with approaches that can be used to explain states' international and domestic actions, and even more theoretical models can be drawn from the adjacent disciplines. To explain the scope of Estonia's counterterrorism measures, this article adopts a reference group perspective, which integrates an explicitly 'social' element into the models of state behaviour and explains how a given government may emulate the counterterrorism policies of some states, but not of others, and how cross-pressures arising from membership in different groups of states are resolved. The reference group theory postulates that a given state's counterterrorism responses are strongly influenced by the 'social groups' of states to which it aspires to gain or maintain membership, or by those states whose material resources or information are necessary for the given state to achieve their political, economic, expressive, and other goals. It is argued here that the reference group theory offers a stronger explanatory account of Estonia's counterterrorism policies than two competing analytical paradigms, namely Rationalism and Constructivism. Additionally, it can be extrapolated to other states and issue-areas extending beyond counterterrorism (Omelicheva 2007). In the context of international relations, Rationalism has become associated with the positivist tradition of explaining policy choices by reference to goal-seeking behaviour (Fearon \& Wendt 2002, p. 54). In a narrower sense, Rationalism explains state behaviour in functional terms: the actor performs an action if the costs associated with it do not exceed the expected benefits from the action. According to this axiom, the magnitude of terrorist violence and national capabilities should determine the scope of states' responses to terrorism. A variant of the Rationalist framework, Realism, would explain Estonia's counterterrorism responses in utilitarian terms as a pursuance of exogenously given self-interest in security under anarchical conditions. It would present Estonia's policies as dependent on NATO, which it sought to join in order to protect its national security from its historical enemy, Russia (Noreen \& Sjöstedt 2004).

However, contrary to the rationalist accounts assuming that states are autonomous actors driven by utility- 
Omelicheva, Mariya Y. Reference Group Perspective on State Behavior: A Case Study of Estonia's Counterterrorism Policies, Europe Asia Studies, 61(3): 483-504, 2009. Publisher's Official Version: <http://dx.doi.org/10.1080/09668130902753317>. Open Access Version: <http://kuscholarworks.ku.edu/dspace/>.

Europe Asia Studies, 61(3): 483-504, 2009.

maximisation concerns, the reference group approach treats states as social actors whose modes of behaviour are strongly influenced by the social groups to which they relate or belong.

In understanding state behaviour in such terms, the reference group perspective comes close to constructivism in that it stresses the importance of social context and the impact of various ideational forces, such as identity, culture and norms. Adopting a constructivist approach, Aalto (2003), Kuus (2002) and Noreen and Sjöstedt (2004), for example, make use of collective identity as an explanatory variable of Estonia's policies within the context of European and North Atlantic security institutions. The notions of collective identity and reference groups are intimately related. The same cognitive processes of categorisation, social comparison, and identification underlie the development of collective identities and the use of reference groups. The view that a state can have multiple collective identities is also shared by both perspectives. Constructivist approaches, however, using the concept of identity, eschew the idea of explaining why states consider that measuring up in relation to the norms and standards of some groups is more important than others, and how states reconcile cross-pressures arising from membership in different social groups. As will be seen below, explaining how the Estonian government resolved what it perceived as the conflicting expectations of the EU and NATO regarding the Iraqi military operation and support for the International Criminal Court would have been challenging within the collective identity framework.

Another weakness of many identity-based perspectives is that they rarely contain a general framework that can illustrate and explain how and why states with particular types of identities act in various social situations (Finnemore \& Sikkink 2001). The reference group approach, on the other hand, illuminates mechanisms and conditions of group identification from which the actions of other states in various issue areas can be inferred. Importantly, the functioning of reference groups does not require the level of identification that makes collective identity virtually non-existent in international relations and extremely difficult to establish empirically. Researchers can plausibly establish states' reference groups based on characteristics enumerated in this study.

The notion of reference groups is also related to the concept of international socialisation. Both share a core sociological insight that agents' behaviour is shaped by the groups to which they belong. A subtle but important difference is that the prevailing understanding of international socialisation defined as a 'process of inducting actors into the norms and rules of a given community' (Checkel 2005, p. 804), 
Omelicheva, Mariya Y. Reference Group Perspective on State Behavior: A Case Study of Estonia's Counterterrorism Policies, Europe Asia Studies, 61(3): 483-504, 2009. Publisher's Official Version: <http://dx.doi.org/10.1080/09668130902753317>. Open Access Version: <http://kuscholarworks.ku.edu/dspace/>.

Europe Asia Studies, 61(3): 483-504, 2009.

retains sociological emphasis on the social context, while the reference group perspective favours a socialpsychological formula presenting behaviour as a function of both the person and the social group. The latter conception stresses the purposeful aspect of state behaviour driven by various goals, and derives expectations about behavioural changes by inspecting the interplay of social forces and their ability to meet states' expressive, utilitarian, and informational needs. It is argued here that in order to gain and maintain their acceptance, political support and other forms of assistance, the Estonian government has closely followed the perspectives and polices of key reference groups, including those in the area of counterterrorism.

\section{The reference group approach to state behaviour}

Originally conceived by social psychologists, the reference group perspective is based on the principle that individuals are influenced by the standards and values of other individuals and groups in making judgments, self-appraisals and behavioural choices (Hyman 1968; Kelley 1952; Newcomb 1958). In the literature of international politics it has been noted that state leaders, too, refer to external models for making policy-related decisions (Agyeman-Duah \& Olatunde 1991; Price 1971; Rivera 2004). It is suggested that the similarity of human social behaviour at different levels of aggregation opens up a possibility for inferring state conduct from individuals' actions. Since it is through their human agents that states interact, form relationships and interpret the behaviour of other states, it can be surmised that states, like individuals, relate and compare themselves to other states (Cronin 1999; Wendt 1999).

States that set and enforce standards of behaviour for other states, or are accepted by the political elites of other states as an appropriate source of information for making judgments about the legitimacy and adequacy of their actions can therefore be seen as a 'reference group'. With respect to counterterrorism specifically, a reference group is a state or a group of states that guides and orients other states' responses to terrorism by endorsing and enforcing principles of counterterrorism activities and by providing information about the legitimacy and effectiveness of counterterrorism measures. Typically, a reference group is an organisation of states to which a given state aspires to join as a member. However, the reference group does not have to be a membership-based international organisation. Neither do states composing the reference group have to engage in dense interactions and form complex interdependencies (Price 1971, p. 404). The reference group is a perception-based social category that does not require face-to-face contact 
Omelicheva, Mariya Y. Reference Group Perspective on State Behavior: A Case Study of Estonia's Counterterrorism Policies, Europe Asia Studies, 61(3): 483-504, 2009. Publisher's Official Version: <http://dx.doi.org/10.1080/09668130902753317>. Open Access Version: <http://kuscholarworks.ku.edu/dspace/>.

Europe Asia Studies, 61(3): 483-504, 2009.

between political elites of different states or regular political, economic and social interactions between states. What matters is that the leadership of two or more countries perceives their states to be members of the same social category.

States emulate the policies of other states for different reasons. A government may adopt a counterterrorism measure endorsed by other states for instrumental reasons, fir example in order to secure material benefits, such as military assistance, or to avoid punishments mediated by others. The group of states that is believed to wield significant power which can be used for providing tangible rewards or imposing material losses on other states is known as a 'utilitarian' reference group. Alternatively a government's emulation of other states' policies may be driven by value-expressive motives, which refer to a state's need to enhance or maintain its positive image and to define itself through the expression of important values and alignment with other groups of states (Herek 1986, p. 106). In this case the group is known as the 'normative' reference group (Hyman 1968; Kelley 1952). To promote its acceptance, the state brings its policies and behaviour into conformity with what is perceived as group's norms and values.

Through this conformity to standards of behaviour of the normative reference group, a state can gain a symbolic sense of acceptance by the group. This outcome can heighten the state's self-image and esteem (Blanton \& Christie 2003, p.123). Finally, when a state lacks complete and accurate information about different aspects of its environment, it will rely on the knowledge provided by other states for making and justifying its policy decisions. The group of states that supplies information, which facilitates states' judgments about the legitimacy and adequacy of their actions is known as a 'comparison' reference group. Comparing its policies against those of the reference group, the government can learn about different aspects of state programmes responsible for their success.

A state, typically, may belong to several utilitarian, normative and comparison reference groups. The prominence of a reference group, its ability to capture the attention of political elites and induce the state's behavioural compliance, is known as the 'salience' of the group. There are several factors that determine the attractiveness of the normative reference group (see Table 1). The most important one is the 'social psychological proximity' developed on the basis of historical, institutional and value similarities (Rose 1993, p. 105; Weil 1993, p. 198). The perceived similarity of important attributes increases affinity among states. The groups of states sharing social, political and institutional characteristics (for example, 
Omelicheva, Mariya Y. Reference Group Perspective on State Behavior: A Case Study of Estonia's Counterterrorism Policies, Europe Asia Studies, 61(3): 483-504, 2009. Publisher's Official Version: <http://dx.doi.org/10.1080/09668130902753317>. Open Access Version: <http://kuscholarworks.ku.edu/dspace/>.

Europe Asia Studies, 61(3): 483-504, 2009.

regime, religion or ethnicity) that are salient to the members of these groups are more likely to be perceived as appropriate normative referents. Among other factors that strengthen the appeal of normative reference groups are the following: the status of the reference group (Majone 1991; Weil 1993); the tangible and intangible benefits of being a part of the reference groups, such as exclusive rights and privileges (Agyeman-Duah \& Olatunde 1991, p. 299); geographical proximity (Mooney 2001); and acceptance by other members of the group. Thus, a state is likely to adopt norms and perspectives of a normative reference group that is perceived as similar to it in some important ways, as having a positive image, or as beneficial to it. When this normative group is also geographically close, the state will be further inclined to identify with the group (Rivera 2004).

States adopt norms and perspectives of the utilitarian reference group for instrumental reasons. The impact of this group of states depends on the intensity of a state's instrumental goals and the ability of the utilitarian group to satisfy them. The size of the group's material resources and its ability to engage in the types of behaviour that can create significant benefits or costs for the state will modify the extent of influence of the utilitarian reference group. Finally, those states that are interested in acquiring new information for finding or optimising solutions to policy problems will turn to comparison reference groups. A group that is believed to have expertise and experience in a specified issue-area is likely to be a role model for other states. What also matters is the perceived similarity or geographical proximity of the comparison group and a borrowing state (Rivera 2004).

\section{[Insert Table 1 About Here]}

As a perception-based social category, reference groups have to be explored at the social psychological level of analysis examining motivations, perceptions and views of the individuals vested with the key tasks of state policy-making. These motivations and views can be inferred from a variety of perceptual and behavioural data such as speech acts, written communications, behavioural reactions, and artefacts of interactions of the states' political elites. This study examines Estonia's political elite's speeches and statements accompanying their political decisions in order to demonstrate conscious policyborrowing for value-expressive, instrumental or informational reasons. In order to establish the existence of a normative reference group, it will be necessary to demonstrate the following: that the Estonian government believed that Estonia shared values and history with its reference groups; that it perceived its 
Omelicheva, Mariya Y. Reference Group Perspective on State Behavior: A Case Study of Estonia's Counterterrorism Policies, Europe Asia Studies, 61(3): 483-504, 2009. Publisher's Official Version: <http://dx.doi.org/10.1080/09668130902753317>. Open Access Version: <http://kuscholarworks.ku.edu/dspace/>.

Europe Asia Studies, 61(3): 483-504, 2009.

relations with the group as beneficial to Estonia's image; and that it adopted the group's policies and perspectives to promote Estonia's acceptance by the group. The utilitarian reference group can be identified on the basis of expressed and inferred state interest in obtaining rewards or avoiding punishment mediated by the group. The comparison reference group can be ascertained through explicit and implicit references to the experiences and expertise of the group as the basis for Estonia's policy emulation.

Since it is the foreign policy makers who maintain relations with other states, and outline directions of the state foreign policy, the focus of the article is on the verbal and written communications of Estonia's key foreign policy players. According to the Constitution of Estonia and the Foreign Relations Act of 1993, the primary foreign policy actors are the Riigikogu (Estonian parliament), the president, the government of Estonia and the Ministry of Foreign Affairs. Consequently, the primary sources of data will be the foreign minister's declarations, statements of foreign policy objectives and addresses to the Riigikogu and international organisations; the president's speeches and addresses pertaining to Estonia's foreign policy; and the Riigikogu's foreign policy decisions, declarations and communications concerning relations between states.

\section{Estonia's reference groups}

In 1991, when Estonia broke away from the Soviet Union, it was deeply concerned about its security and independence. About 10,000 fully trained and de-mobilised Soviet troops-five times as big as Estonia's poorly equipped defence forces - occupied the republic. Russia insisted on keeping its military forces in the Baltic region to counter what it perceived as the main threat to Russian interests from the so-called 'New Abroad' (Trofimov 1992). Thus, Estonia's main goal in the early 1990s was the removal foreign troops and safeguarding its national security from the threat of Russia, and Estonia's leaders acknowledged that the country could not achieve this by itself (Ojuland 2002). '[Estonians] can guarantee [their] security through collective security arrangement of an alliance. At present, the only such an alliance is NATO', declared the speaker of the Riigikogu, Ulo Nugis, in October 1991 (Riim 2006, p. 49).

A further important foreign policy goal was to transform Estonia's image from second tier postcommunist state into a European state (Ilves 1999a). The Estonian government was strongly motivated to shed the label of a 'former Soviet republic' and strengthen Estonia's international position. As Toomas Hendirk Ilves explained, 'due to [Estonia's] size, history, and geographical location, we are much more 
Omelicheva, Mariya Y. Reference Group Perspective on State Behavior: A Case Study of Estonia's Counterterrorism Policies, Europe Asia Studies, 61(3): 483-504, 2009. Publisher's Official Version: <http://dx.doi.org/10.1080/09668130902753317>. Open Access Version: <http://kuscholarworks.ku.edu/dspace/>.

Europe Asia Studies, 61(3): 483-504, 2009.

concerned with our external identity than most countries. And so we should be. As a small country, we must constantly develop our international image' (Ilves 1999b, p. 3).

To receive security guarantees and recognition as a European state, Estonia's government zealously pursued integration into the Euro-Atlantic organisations. This became a leitmotiv of the Estonian government's discourse and a guiding principle of its foreign and public policy. Membership of the NATO collective security system was viewed as a powerful deterrent to Russia's hostile ambitions, while being a part of the EU 'carried with it a powerful marker of inclusion and identification as "Western" and "European", (Laffan 2004, p. 75). Representative democracy, commitment to human freedoms and respect for the rule of law are essential characteristics shared by all members of the European Union (Laffan 2004, p. 81). NATO, too, has made protection of these principles and values its watchword (NATO 1991, 1999; Riim 2006). To warrant entry into NATO and the EU, Estonia's politicians stressed the commonality of values between Estonia and these organisations. In foreign policy statements delivered at the European Parliament, at Western universities, and during EU and NATO meetings, Estonian policy makers stressed that their republic valued above all democracy, freedom, peace and the rule of law. The declared continuity between the modern republic of Estonia and the parliamentary republic established in 1920 was intended to give credence to the proclaimed value of representative democracy as a backbone of the Estonian independent statehood.

Thus, for Estonia NATO and the EU became the most significant reference groups. The norms, practices and perspectives of NATO and the EU have strongly influenced Estonia's views on world politics and have been employed as the benchmarks for Estonia's policies by the republic's political elites. In his study of Estonia's national interest, Toomas Riim (2006) traces changes in the discourse and defence policies of Estonia's leadership to the transformation of NATO's strategic vision. To muster the Alliance's support, the Estonian government adopted NATO's perspectives on security issues, and implemented extensive military reforms to bring its defence policies and institutions in line with those of NATO (Riim 2006, p. 41). Estonia also committed itself to the fight for democracy, international crisis management and peace operations, especially where NATO had been involved (Ojuland 2002).

To become a member of the EU, Estonia used the Union's foundational principles and values as a yardstick for its domestic and foreign policy actions and reforms, especially from 1994 onwards (Ilves 
Omelicheva, Mariya Y. Reference Group Perspective on State Behavior: A Case Study of Estonia's Counterterrorism Policies, Europe Asia Studies, 61(3): 483-504, 2009. Publisher's Official Version: <http://dx.doi.org/10.1080/09668130902753317>. Open Access Version: <http://kuscholarworks.ku.edu/dspace/>.

Europe Asia Studies, 61(3): 483-504, 2009.

1999b). After submitting its membership application in 1995, Estonia brought its domestic legislation into accordance with more than 12,000 legal acts constituting the EU legislative framework. Estonia has consistently joined declarations and common opinions expressed by the EU institutions, and participated in several common actions undertaken by the organisation (Estonian Ministry of Foreign Affairs 2001a). According to Toomas Hendrik Ilves, Minister of Foreign Affairs of Estonia, 'the European Union has, and will continue to have, a strong impact on how [Estonians] regard [themselves] in relation to the outside world as well as how [they] are perceived by others' (Ilves 1999b, p.3).

Initially, NATO and, to a lesser degree, the EU, served Estonia's instrumental goals in that they provided 'hard' and 'soft' security guarantees against a historical source of threat to Estonia's independence posed by Russia (Riim 2006, p. 41). ${ }^{1}$ Under considerable political pressure from Estonia's Western partners, Russia withdrew its troops from Estonian territory in the autumn of 1994. Then, as a member of NATO, Estonia received additional security guarantees under Article 5 of the North Atlantic treaty, as well as other economic and security benefits (Ilves 1997). As a candidate for EU and NATO membership, Estonia received ample assistance for its policy reforms. Membership of the EU opened up the Union's market to Estonian companies, workers, students and tourists who received greater opportunities for exporting products, working and studying as well as moving around within the borders of the EU.

At the same time, NATO, and especially, the EU have become important normative groups which Estonia aspired to join. Membership in these organisations was perceived as extremely beneficial to Estonia's self-concept and international image. 'Our EU prospects have improved our overall status on the international arena', declared Minister of Foreign Affairs Ilves, in 1999 (Ilves 1999b). Kristiina Ojuland, Minister of Foreign Affairs of Estonia in 2002, affirmed that 'membership in NATO will begin to boost Estonia's image in the foreign policy sphere' (Ojuland 2002, p. 3). Estonia also received wide-ranging informational support from NATO and the EU that was instrumental in carrying out its policy reforms as well as an opportunity to make use of valuable expertise and advice provided by policy specialists of these organisations. For example, the Nordic states, and the American and British governments provided Estonia

1 See also Tiido, H. 'Security', 18 September 2003, available at: http://www.vm.ee/estonia/kat_400/ pea_172/2080.html, accessed 7 November 2007. 
Omelicheva, Mariya Y. Reference Group Perspective on State Behavior: A Case Study of Estonia's Counterterrorism Policies, Europe Asia Studies, 61(3): 483-504, 2009. Publisher's Official Version: <http://dx.doi.org/10.1080/09668130902753317>. Open Access Version: <http://kuscholarworks.ku.edu/dspace/>.

Europe Asia Studies, 61(3): 483-504, 2009.

with considerable assistance in revamping its military and defence systems. The EU, NATO, and member states of these organisations, supplied the Baltic states with the necessary personnel for the preparation, drafting and implementation of the new laws (Appelquist 2003, p. 81; Estonian Ministry of Defence 2002).

NATO and the EU, which provided Estonia with important security guarantees, opportunities for development and international recognition, have become the republic's primary utilitarian and normative groups. The transatlantic organisations have also served Estonia's informational needs by providing the republic with wide-ranging informational and knowledge support. Estonia has intensified its commitment to the realisation of EU and NATO goals by increasing development assistance, a serious challenge for Estonia's budget. It has raised the number of servicemen deployed in peacekeeping operations abroad because those measures are viewed as contributing to peace and the promotion of democracy around the world. Both NATO and the EU have made protection of these principles their watchword (Eesmaa 2005).

Strong historical and cultural ties, as well as common foreign policy goals unite Estonia with Latvia and Lithuania. Yet, these nations did not become Estonia's primary referents. Neither did the Nordic states-Denmark, Finland, Iceland, Norway and Sweden — with which Estonia has always had amicable and cooperative relations. The Estonian government rejected the existence of a Baltic Defence Community or a Baltic Union as alternatives to membership of NATO and the EU (Assembly of Western European Union 2004). For Estonia's officials, intense cooperation with the Baltic and Nordic states was a strategic necessity stemming from the need for assistance with Estonia's integration to the Euro-Atlantic organisations (Estonian Ministry of Foreign Affairs 2001b). It also helped to resist political pressure from Russia. By participating in security and defence projects with the other Baltic states, Estonia was able to pool available resources with its neighbours and more effectively channel external assistance in the field of defence.

\section{The counterterrorism policies of Estonia's reference groups}

\section{NATO}

Combating terrorism was not envisioned among the foundational goals of the North Atlantic Treaty Organization (NATO 1991; Riim 2006). It was the 9/11 attacks that thrust the alliance into the fight against global terrorism. For the first time ever, NATO invoked a 'collective defence clause', declaring terrorist 
Omelicheva, Mariya Y. Reference Group Perspective on State Behavior: A Case Study of Estonia's Counterterrorism Policies, Europe Asia Studies, 61(3): 483-504, 2009. Publisher's Official Version: <http://dx.doi.org/10.1080/09668130902753317>. Open Access Version: <http://kuscholarworks.ku.edu/dspace/>.

Europe Asia Studies, 61(3): 483-504, 2009.

attacks on American soil as an attack against all NATO members (Ayliffe 2005, p. 4). This set an important precedent for NATO's involvement in military operations outside of Europe. NATO's engagement in the military campaign in Afghanistan provided an impetus for the development of the alliance's Military Concept against Terrorism (hereinafter, the Concept). Adopted in November 2002, the Concept differentiates between anti-terrorism and counterterrorism military operations (NATO 2002b). The former encompasses various defensive measures designed to reduce the vulnerability of allies' forces, people and property to terrorism, whereas the latter includes offensive military operations designed to reduce terrorists' capabilities. The counterterrorism (offensive) measures are given primary attention in the document. The Concept legalises pre-emptive strikes by authorising the North Atlantic Council to make decisions regarding the deployment of the Alliance's military forces against terrorist bases and sanctuaries, provided that the threat of terrorism is 'severe enough'.

At the 2002 Prague Summit, NATO's member nations made a commitment to improve the Alliance's military capabilities to fight new global threats through the creation of the NATO Response Force (NRF), which was earmarked for counterterrorism operations (NATO 2002a). NRF troops are contributed by the members of NATO. Consequently, the allies are required to ensure that their forces meet NATO’s criteria of deployability, readiness, interoperability and flexibility.

Although, the Concept for Defence against Terrorism reaffirms the position that NATO's military operations will conform to international human rights and humanitarian law, the Alliance's forces have been accused of serious violations of the laws of war leading to the unlawful killings of civilians (Amnesty International 2000). According to the New York-based Human Rights Watch, "while NATO forces try to minimise harm to civilians, they obviously are not doing enough ... . NATO's tactics are increasingly endangering the civilians that they are supposed to be protecting, and turning the local population against them' (Human Rights Watch 2006, p. 1). NATO's new mission of promoting and imposing peace and democracy worldwide, by force if necessary, has also been criticised as inconsistent with human rights standards (Amnesty International 2000).

\section{European Union}

The 9/11 terrorist attacks provided a new momentum for EU counterterrorism legislative initiatives and law-enforcement cooperation between its members (Archick 2005). Although terrorism has been a big 
Omelicheva, Mariya Y. Reference Group Perspective on State Behavior: A Case Study of Estonia's Counterterrorism Policies, Europe Asia Studies, 61(3): 483-504, 2009. Publisher's Official Version: <http://dx.doi.org/10.1080/09668130902753317>. Open Access Version: <http://kuscholarworks.ku.edu/dspace/>.

Europe Asia Studies, 61(3): 483-504, 2009.

concern to several European states for decades, joint efforts at combating terrorism have been stalled due to the lack of resources and difficulties with the coordination of numerous European agencies (Lugna 2006, pp. 101-2).

The Union's legislative efforts culminated in the adoption of the Hague Programme for Freedom, Justice and Security (hereafter, the Hague Programme) in November 2004. The Hague Programme systematises EU measures aimed at enhancing security in Europe over a five-year period in four areas: prevention, protection, prosecution and response (EU Council 2005). The goal of the EU preventive measures is to halt the radicalisation of groups and the recruitment of individuals by identifying and offsetting the methods, propaganda and conditions through which individuals are drawn into terrorism. The protective measures aim at reducing the vulnerability of the European people and European infrastructure to terrorist attacks with particular emphasis on the improvement of the security of border, transport and critical facilities. The cross-border investigation of terrorist acts and the impeding of terrorists' communications, travel, financial and other forms of support fall within the category of pursuit within the European counterterrorism strategy. The response measures, such as the development of risk assessment tools and approaches for the provision of assistance to victims of terrorism, are designed to cope with and minimise the consequences of terrorist attacks (EU Council 2005).

To facilitate supranational efforts at combating terrorism, the EU set up new institutions or increased the powers of existing agencies. On 28 February 2002, the EU created Eurojust with the aim of improving the coordination of and cooperation between investigators, prosecutors and judicial authorities dealing with terrorism and other serious cross-border crimes (Lugna 2006, p. 114). In October 2004, the European Council set up the European Border Agency for coordinating and assisting operational cooperation between member states in the area of management of external borders. Europol, an EU law enforcement agency charged with the task of criminal intelligence, received additional resources for examining the risks and threats associated with terrorism and for enhancing its role in the field of informational exchange (EU Council 2004).

Every document advancing European integration in the area of counterterrorism contains references and assertions of commitments to the protection of fundamental human freedoms. The official position of the EU concerning the issue of human rights and terrorism has been a firm and unequivocal 
Omelicheva, Mariya Y. Reference Group Perspective on State Behavior: A Case Study of Estonia's Counterterrorism Policies, Europe Asia Studies, 61(3): 483-504, 2009. Publisher's Official Version: <http://dx.doi.org/10.1080/09668130902753317>. Open Access Version: <http://kuscholarworks.ku.edu/dspace/>.

Europe Asia Studies, 61(3): 483-504, 2009.

rejection of inhuman and derogatory practices and condemnation of the indiscriminate use of force. EU practice has generally followed the official position. The EU set up necessary institutions, promoted peer review and public monitoring practices with the aim of ensuring the protection of fundamental human rights. The European Union agencies have repeatedly condemned counterterrorism operations that appeared to contradict the principle of proportionality and respect for individual human rights (Ministry for Foreign Affairs of Finland 1999). ${ }^{2}$

Estonia's counterterrorism policies: an emulation of the reference groups' responses to terrorism

Who are Estonians fighting?

Estonia's security and intelligence officials affirm that their country faces a minimal threat of terrorism (Baltic News Service 2004a, 2005). The extensive counterterrorism measures adopted by the Estonian government have been explained by the republic's willingness 'to fulfil its role in the ongoing quest for comprehensive international security' (Ojuland 2002, p. 3). Estonia's public officials believe that in the increasingly interdependent international security environment "no nation or region of the world is beyond danger' (National Security Concept of the Republic of Estonia 2004, p. 5). This belief in the interconnectedness of global security threats and the importance of collective security measures resonates with ideas underpinning the counterterrorism programmes of NATO and the EU. The counterterrorism initiatives of these organisations have been guided by the principle that no single country or region can cope successfully with terrorism and that national and international security are indivisible (de Vries 2004; NATO 1999).

Another explanation in the public statements of Estonia's politicians is that of safeguarding democratic values. Through its participation in the fight against terrorism Estonia hopes to contribute to the defence of democracy and freedom in the world (Estonian Ministry of Foreign Affairs 2002a, 2003a; Paet 2006). This approach corresponds to the position promoted by European and transatlantic organisations. Both NATO and the EU declared terrorism to be a threat to democracy, the free exercise of human rights

2 See also 'European Parliament Condemns Killing of Maskhadov', Chechen Times, 27 May 2005, available at: http://www.chechentimes.org/en/comments/?id=29251, accessed 7 November 2007. 
Omelicheva, Mariya Y. Reference Group Perspective on State Behavior: A Case Study of Estonia's Counterterrorism Policies, Europe Asia Studies, 61(3): 483-504, 2009. Publisher's Official Version: <http://dx.doi.org/10.1080/09668130902753317>. Open Access Version: <http://kuscholarworks.ku.edu/dspace/>.

Europe Asia Studies, 61(3): 483-504, 2009.

and economic and social development (EU Council 1995, 2005). Any state founded on these principles shares a responsibility for protecting these values against the threat of terrorism.

Preventing terrorism: the influence of the EU counterterrorism programme

The analysis of risks and trends of terrorism constitutes an important element of the 'prevention' aspect of the EU counterterrorism strategy. In fulfilment of this goal, all member states are required to identify factors contributing to the recruitment of terrorists (EU Council 2005). The antiterrorist strategy in Estonia also prioritises the analysis of potential threats. According to official reports, Estonia's investigative and intelligence authorities have been engaged in risk analysis at the central and regional levels. Investigative authorities have been exploring trends of financing terrorism using intelligence information for tracing terrorist funds and financial assets (UN Security Council 2003, 2005).

The 'protection' aspect of the EU counterterrorism programme requires states to enhance the protection of the EU's external borders, and raise standards in transport and infrastructure security (EU Council 2005). Estonia's leaders have repeatedly stated their commitment to fulfilling Estonia's international obligations, such as stringent securing of the republic's borders, airports, seaports and banking infrastructure (Ilves 2001). The Security Police Board of Estonia (Kaitsepolisei) provided the Border Guards with lists of possible terrorists and individuals associated with terrorists. These data have been used to improve border checks on individual travellers. The government of Estonia has also installed modern document control equipment at the major border crossing points and reformed Estonia's export control legislation and practices to meet the criteria established by EU regulations. The Estonian government strengthened civil aviation security measures and introduced amendments to the Aviation Act and the Maritime Safety Act (UN Security Council 2001, 2002).

To achieve the aims of the third, 'pursuit' aspect of the EU counterterrorism strategy, member states are expected to strengthen their national capabilities to combat terrorism, carry out cross-border investigation of terrorist acts, and detect and disrupt terrorists' financial channels, communications and travel. In Estonia, the Security Police Board plays the primary direct role in combating terrorism (Spencer 2006). Since the $9 / 11$ attacks, the Security Police have taken numerous measures to strengthen its counterterrorism capabilities and activated surveillance. It established cooperative relations with Europol and Eurojust on the basis of agreements signed by Estonia's government with these organisations. It also 
Omelicheva, Mariya Y. Reference Group Perspective on State Behavior: A Case Study of Estonia's Counterterrorism Policies, Europe Asia Studies, 61(3): 483-504, 2009. Publisher's Official Version: <http://dx.doi.org/10.1080/09668130902753317>. Open Access Version: <http://kuscholarworks.ku.edu/dspace/>.

Europe Asia Studies, 61(3): 483-504, 2009.

intensified joint anti-terrorism measures with the Baltic states and members of the Council of the Baltic Sea States, which, beside Estonia, Latvia and Lithuania, includes Poland, Germany, Denmark, Norway, Sweden, Finland and Russia.

Security Police Board officials working on counterterrorism issues have been trained in various techniques for investigating terrorism-related offences, managing risks and the proper utilisation of sophisticated equipment for detecting weapons of mass destruction and hazardous materials. Specialists from the EU and NATO shared their expertise with the Estonian security services officials (Adra 2002; US Department of State 2006). The EU, NATO, and their individual member states provided necessary equipment and financial support for training the Estonian police.

\section{Military preparedness and participation: the influence of NATO's counterterrorism measures}

In view of NATO's contemporary goals and its emphasis on the development of rapid response forces, the Estonian government expended significant effort to improve the republic's military capabilities. Estonia developed modern, multi-purpose, redeployable, mobile and sustainable rapid reaction units that meet NATO's standards (Ilves 2001). Building on the promises of support and assistance to NATO's counterterrorism and peacekeeping operations, Estonia contributed a de-mining team within the framework of the International Security Assistance Force (ISAF) in Afghanistan, a cargo-handling team, and a 24-man infantry platoon. It also provided humanitarian and other forms of assistance within the framework of the operation Enduring Freedom (Ilves 2001; US Department of State 2006).

Estonia's military has engaged in numerous counter-terrorism exercises with other members and partners of NATO to strengthen interactions among NATO counter-terrorism units and synchronise communications, support and combat (Estonian Ministry of Foreign Affairs 2002b, 2005). Estonia has also assisted with the development of third countries' operational capabilities in accordance with the NATO Partnership Action Plan against Terrorism (Ilves 2001).

\section{Explaining Estonian emulation of its partners}

The measures enacted by the Estonian government in the area of counterterrorism and the discourse surrounding their adoption demonstrate that EU and NATO views on the threat of terrorism and their counterterrorism policies have had a strong bearing on Estonia's responses to terrorism. Estonian officials 
Omelicheva, Mariya Y. Reference Group Perspective on State Behavior: A Case Study of Estonia's Counterterrorism Policies, Europe Asia Studies, 61(3): 483-504, 2009. Publisher's Official Version: <http://dx.doi.org/10.1080/09668130902753317>. Open Access Version: <http://kuscholarworks.ku.edu/dspace/>.

Europe Asia Studies, 61(3): 483-504, 2009.

had not begun voicing concerns about the risks posed by terrorist networks and expanding its anti-terrorism measures until NATO and the EU had adopted statements and documents alluding to the threat of international terrorism, had revitalised their counterterrorism programmes and intensified member states' law-enforcement and defence cooperation. As Ilves has explained, 'For Estonia, as a responsible state which shares common values [with the EU], it is useful to also adopt, within [Estonia's] means, all antiterrorist measures which have been approved by the EU' (Ilves 2001, p. 4). In the same speech, in reference to NATO's anti-terrorism coalition he affirmed: 'It is Estonia's duty to be a contributing part of this coalition. The necessity of fighting terrorism, and the participation in this struggle are concrete reasons for Estonia to be an integral part of the Euro-Atlantic security sphere' (Ilves 2001, p. 1).

Estonia's politicians have consistently alluded to their country's responsibility to take part in the common defence of the transatlantic security space. Estonia's government has carried out diligently the republic's assumed duty. All this suggests that the EU and NATO exerted strong normative influence on Estonia's counterterrorism responses. The organisations established standards of appropriate and acceptable counterterrorism policies which Estonia's government chose to pursue in order to promote acceptance by the groups. At the same time, NATO and, to a lesser extent, the EU has also played an instrumental role in Estonia's foreign policy. This can be evidenced in the following statement justifying Estonia's intention to take part in NATO's counterterrorism operations: 'Presuming, that as a future ally, [the Estonians] have the right to expect aid in a crisis situation, [they] have to be ready to fulfil [their] role in the structure, which ensures [their] common security' (Ilves 2001, p. 1).

If Estonia's contribution to EU and NATO counterterrorism programmes had been only a pragmatic choice of the Estonian government prior to Estonia's integration in the Euro-Atlantic security structures, then as a member of the EU and NATO, the republic should have relinquished or limited its sizable and very unpopular human and financial contributions to the organisations' counterterrorism efforts. However, Estonia has increased the size of its military forces participating in foreign operations in Iraq, Afghanistan and the Balkans. In 2006, Estonia's government announced plans to have $8 \%$ of the republic's troops deployed in NATO-led operations, and $40 \%$ of the servicemen be prepared for such deployment by the year of 2010 (Paet 2006). The same year, Estonia doubled its development assistance and the government intends to increase the amount of aid up to $0.1 \%$ of the republic's GDP, in conformity with the 
Omelicheva, Mariya Y. Reference Group Perspective on State Behavior: A Case Study of Estonia's Counterterrorism Policies, Europe Asia Studies, 61(3): 483-504, 2009. Publisher's Official Version: <http://dx.doi.org/10.1080/09668130902753317>. Open Access Version: <http://kuscholarworks.ku.edu/dspace/>.

Europe Asia Studies, 61(3): 483-504, 2009.

UN Millennium goals (Easmaa 2005). It is not for the protection of Estonia's physical security or for the receipt of economic benefits that the Estonian government has engaged in the development assistance programmes. Instead, these measures have been viewed as a vehicle for disseminating democratic values and promoting economic stability - 'the best means of safeguarding peace' and defence against terrorism, according to Estonia's officials (Security Police Board of Estonia 2007). Estonia's deepening engagement in global security and development projects illustrate how the posture of peace, economic development and democratic values, which lie at the heart of the EU and NATO, have become interpreted in terms of Estonia's national interest.

Reconciling differences in the counterterrorism approaches of NATO and the EU: the invasion of Iraq and human rights

The counterterrorism policies of NATO and the EU, for the most part, reinforce and complement each other. There are, however, several aspects of their fight against terrorism related to the use of force, multilateralism and the primacy of human rights, on which NATO and the EU differ. The European Union's endorsement of a military response has traditionally been based on an adherence to the rule of international law, particularly to Article 51 of the UN Charter on self-defence, and on the broad international consensus embodied in the United Nations' regulations on the use of military force (Rees \& Aldrich 2005, p. 915). The Alliance's security concept of 1991 and 1999, on the other hand, do not require the conformity of NATO's military operations with the relevant provisions of the UN Charter. NATO's Concept for Defence against Terrorism pinpoints the possibility of using the Alliance's troops in preemptive military operations without UN approval.

The Iraqi crisis laid bare these differences on the appropriateness of the use of force, and the importance of the principle of multilateralism in international efforts to curb the threat of terrorism. As a member of both NATO and the EU, Estonia was confronted with the difficult task of reconciling or choosing between the conflicting counterterrorism policies of its membership groups. In the run-up to the military operation in Iraq, Estonia's leaders expressed strong backing of the multilateral UN-led initiative to resolve the Iraqi nuclear weapons' impasse (Ojulandi 2002). Yet, when American forces landed in Iraq, Estonian politicians supported the war. That decision was a difficult one since it was clearly inconsistent with the norms and principles of the EU, and the Estonian public disapproved of their state's engagement in 
Omelicheva, Mariya Y. Reference Group Perspective on State Behavior: A Case Study of Estonia's Counterterrorism Policies, Europe Asia Studies, 61(3): 483-504, 2009. Publisher's Official Version: <http://dx.doi.org/10.1080/09668130902753317>. Open Access Version: <http://kuscholarworks.ku.edu/dspace/>.

Europe Asia Studies, 61(3): 483-504, 2009.

military combat. The reference group perspective can offer insight into the Estonian government's political choices.

The final stages of the NATO enlargement process and the escalation of the Iraq crisis developed against the background of the Kremlin's renewed ambitions over spheres of influence (Made 2005). NATO, in the opinion of Estonia's leadership, has been the only international structure capable of safeguarding Estonia's independence and security from its historical threat, Russia. Estonia's leaders were well aware that the republic's membership of NATO could only be secured if NATO's leading nation, the USA, ratified Estonia's accession agreement. It was reasoned that active military participation in Iraq would make a strong emotional impact on the USA (Ilves 2002; Made 2005). Subsequently, the Estonian government made a pragmatic choice 'determined by the reality of international power politics and what [Estonia] felt was required in the run-up to NATO accession' (Assembly of Western European Union 2004, p.21).

This pragmatic choice was further substantiated by normative reasons. In the so-called 'Vilnius Group of $10^{\prime}$ statement on Iraq the representatives of NATO candidate states declared:

Our countries understand the dangers posed by tyranny and the special responsibility of democracies to defend our shared values. The transatlantic community, of which we are a part, must stand together to face the threat posed by the nexus of terrorism and dictators with weapons of mass destruction. (Estonian Ministry of Foreign Affairs 2003b)

Estonia joined the US-led coalition in Iraq and sent over 50 servicemen to the country in June 2003. It is notable that the government of Estonia has described its activities in Iraq as participation in NATO operations (Estonian Ministry of Foreign Affairs 2003a). It even claimed that the practical experience of Estonia's servicemen in the war zone would increase the preparedness of Estonian troops for participation in NATO's rapid response forces. By October 2004, more than 140 Estonian military personnel had served in Iraq. On 28 March 2004 the US Senate ratified the NATO Accession protocol of the seven new members and a day later Estonia became a de jure member of the Alliance. 
Omelicheva, Mariya Y. Reference Group Perspective on State Behavior: A Case Study of Estonia's Counterterrorism Policies, Europe Asia Studies, 61(3): 483-504, 2009. Publisher's Official Version: <http://dx.doi.org/10.1080/09668130902753317>. Open Access Version: <http://kuscholarworks.ku.edu/dspace/>.

Europe Asia Studies, 61(3): 483-504, 2009.

Thus, in the case of the Iraqi military crisis, Estonia followed what it perceived as NATO's perspective on the military operation in the Middle East. The salience of NATO at that time stemmed from its ability to satisfy Estonia's immediate security needs. 'The EU', according to Ilves, 'is not a security organisation and we do not regard membership in the EU as a security guarantee' (Ilves 1999a). According to Estonian diplomat Harri Tiido, 'the only "hard" security guarantee which Estonia can accept is membership in the North Atlantic Alliance, as NATO is the only structure capable of providing security for its members...' (Tiido 2003).

The European Union never explicitly formulated its policy toward the war in Iraq and the Union's ambiguous position on the candidate states' participation in the US-led coalition allowed Estonia to proceed with discretion in the Iraqi case. However, where the EU position is made explicit, as in the case of the immunity agreements with the US, Estonia follows EU norms and principles. After the commencement of the US military operation in Afghanistan, the US government began exerting strong pressure on the parties of the International Criminal Court (ICC) to sign agreements, exempting US servicemen and citizens from ICC jurisdiction. Estonia's leadership was tempted to take the American side in order to secure US approval for Estonia's membership of NATO. Yet, it did not sign an immunity agreement with the US, despite economic sanctions imposed by the US administration. ${ }^{3}$ The EU has unequivocally conveyed its position on the issue of human rights protected by the ICC and the signing of the immunity agreement with the US was framed as a violation of the Union's foundational values (Council of Europe Parliamentary Assembly 2002; World Federalist Association 2002). It was also viewed as inconsistent with the principles that NATO purported to defend. This breach of these principles posed a threat to Estonian identity as a European democratic state.

After Estonia anchored itself in the transatlantic organisations, it was expected that the Estonian government would withdraw its servicemen from Iraq since American patronage was no longer important to Estonia. No weapons of mass destructions were found in Iraq, and the deplorable situation in the country deprived the invasion of its original purpose of spreading democracy to the Middle East. After Estonia suffered its first casualties, the Estonian public's disapproval of the republic's engagement in Iraq reached

${ }^{3}$ On July 1, 2003 the US cut off its military assistance to those states which had not signed an Article 98 treaty. The prohibitions of military assistance have only been waived with respect to certain projects that were considered necessary to assist in integration of the candidate states to NATO. 
Omelicheva, Mariya Y. Reference Group Perspective on State Behavior: A Case Study of Estonia's Counterterrorism Policies, Europe Asia Studies, 61(3): 483-504, 2009. Publisher's Official Version: <http://dx.doi.org/10.1080/09668130902753317>. Open Access Version: <http://kuscholarworks.ku.edu/dspace/>.

Europe Asia Studies, 61(3): 483-504, 2009.

an all time high. However, although, some voices in the Estonian administration insisted on pulling out Estonia's forces from the Middle East, the Estonian government and parliament decided to extend the deployment of Estonian servicemen in Iraq. The reason behind this policy choice was not the fear of political isolation or the prospect of disappointing the United States; rather, Estonia's decision was driven by an understanding of the continuity between the dispatch of the Estonian troops to Middle East and Estonia's commitments to the EU and NATO's principles concerning the defence of democratic values. The government acknowledged its responsibility towards returning stability in Iraq, and while sectarian violence continued to engulf the state, the Estonian government decided that it was not possible to withdraw troops (Easmaa 2005). Thus, the extension of Estonia's mission in the Middle East has been the result of the normative influence of Estonia's reference groups.

The Estonian government has become more vigilant in ensuring the consistency of its activities under the auspices of NATO with the principles and priorities of the EU. The government of Estonia has repeatedly underscored the importance of multilateralism (expressed in the UN-spearheading role), broad consensus and partnership in resolving the Iraqi post-war crisis (Baltic News Service 2004b). Only after the UN Security Council decided to extend the mandate of the US-led force in Iraq, thus, confirming the international legitimacy of the continuation of the mission, did the Estonian administration approve the continuation of Estonian servicemen in Iraq (Agence France Presse 2005).

\section{Discussion and conclusions}

The goal of this study was to explain the scope of the counterterrorism policies of Estonia, which, in the absence of terrorist threat, adopted a broad spectrum of measures aimed at combating terrorism in different areas of public and foreign policy. The reference group perspective was used to demonstrate that social groups of states, whose membership other states aspire to gain or maintain, or which offer material resources or information necessary for other states to achieve their political, economic, or other goals, exert strong influence on such other states' counterterrorism responses.

The magnitude of terrorist violence and states' material capabilities that have been viewed by rationalist approaches as the key determinants of governments' responses to terrorism are insufficient for explaining Estonia's counterterrorism policies. A principle weakness of these accounts of states' behaviour is that they neglect the wider context of inter-state relations in which governments interpret the extent of 
Omelicheva, Mariya Y. Reference Group Perspective on State Behavior: A Case Study of Estonia's Counterterrorism Policies, Europe Asia Studies, 61(3): 483-504, 2009. Publisher's Official Version: <http://dx.doi.org/10.1080/09668130902753317>. Open Access Version: <http://kuscholarworks.ku.edu/dspace/>.

Europe Asia Studies, 61(3): 483-504, 2009.

terrorist threat and assess the effectiveness and acceptability of the means for fighting terrorism. And constructivist approaches that do recognise the normative or socialising impact exerted by other states fall short of enumerating factors that make the perspectives of some states more attractive than others as models, and lack a general framework of mechanisms and scope conditions under which different types of influence work.

By contrast a significant merit of the reference group approach is in its interrogation and disaggregation states' interests and goals, and examining them through the prism of history, existing political configurations and the socio-economic milieu. Internationally, states operate in a number of social settings. Each international institution can be more or less actively involved in socialising potential members into the behavioural modes that it approves of. Socialisation approaches have grappled with striking differences in the pace and depth of international socialisation (Checkel 2005). The reference group approach explains this variation by the strength of states' motivations and the ability of social groups to serve their most salient needs. Additionally, the literature on socialisation favours an assumption of international organisations as triggers of socialisation that push for the induction of states into their community of values and norms. In practice, however, individual states, themselves, may eagerly seek identification and social integration based on the definition of what constitutes their national goals and needs. In case of the countries of Central and Eastern Europe, including Estonia, the states' desire to change their position from non-allied to allied nations preceded any active socialising efforts of the institutions they wanted to join (Gheciu 2005; Noreen \& Sjöstedt 2004, p. 741).

All in all, the reference group perspective does not contradict the idea of international socialisation. Instead, it systematises the mechanisms and scope conditions (see Table 1) under which different types of social influence occur. Studies examining how and why states adopt new behavioural modes and roles typically privilege either the rational choice or the socialisation approach (Johnson 2005), and catalogue multifarious processes_-bargaining, persuasion, teaching or learning — through which international socialisation can take place (Zürn \& Checkel 2005). The reference group perspective provides an integrative framework of normative, strategic and psychological sources of international influence on the assumption that by studying the interplay of strategic behaviour with social and psychological forces our understanding of how states transform their views and policies can be considerably improved. 
Omelicheva, Mariya Y. Reference Group Perspective on State Behavior: A Case Study of Estonia's Counterterrorism Policies, Europe Asia Studies, 61(3): 483-504, 2009. Publisher's Official Version: <http://dx.doi.org/10.1080/09668130902753317>. Open Access Version: <http://kuscholarworks.ku.edu/dspace/>.

Europe Asia Studies, 61(3): 483-504, 2009.

As noted above, for over a decade, Estonia has been untouched by terrorist violence and less than $5 \%$ of the Estonian public regards terrorism as a national problem (European Commission 2004). The present analysis found that it was not until NATO and the EU brought the issue of terrorism to the fore of their security concerns that the Estonian governments began tackling the threat of terrorism, and Estonia's views on terrorism have always corresponded to the position promoted by the EU and NATO. Although this study and the related research have confirmed that the threatening posture of Russia was a major concern that propelled the Estonian government to seek security guarantees from NATO, this threat had dissipated even before the century's turn. After the Kremlin withdrew its troops from Estonia, the Estonian government began downplaying the threat of Russia in favour of other political concerns (Aalto 2003; Noreen \& Sjöstedt 2004). Furthermore, Estonia as well as other second-wave candidates to NATO adopted a series of costly political actions and military reforms without any assurances that they would receive the reward of membership and the desired protection of NATO (Gheciu 2005, p. 974). Therefore, the fear of Russia cannot completely account for Estonia's counterterrorism policies and reforms.

There are multiple avenues for developing the reference group theory further and extending its empirical reach outside of the European space. For instance, in the case of Estonia, the locus of both utilitarian and normative influence coincided in the same groups of states, and the counterterrorism policies of the EU and NATO have had a complementary nature. Therefore, it has been largely unproblematic for Estonia to transpose its counterterrorism legislation, establish necessary institutions, and adopt other policies promoted by these organisations in the field of counterterrorism. A greater empirical challenge would be to study those cases where the seat of the normative and utilitarian influence is split among several groups of states, and where different social groups put forth conflicting expectations of their members' behaviour. Another direction for future research is to investigate further the mechanisms and scope conditions under which a shift from behavioural compliance based on a cost-benefit calculation to normative conformance based on the internalisation of groups' norms takes place. The logical range of possible internationalisation and identity change also needs more elaboration and investigation.

Adopting a group's perspectives for value-expressive reasons translates to the internalisation of the group's norms, and any deviation from the course of actions promoted by the normative group should create a meaningful threat to state identity. The Estonian government believes that the republic's 
Omelicheva, Mariya Y. Reference Group Perspective on State Behavior: A Case Study of Estonia's Counterterrorism Policies, Europe Asia Studies, 61(3): 483-504, 2009. Publisher's Official Version: <http://dx.doi.org/10.1080/09668130902753317>. Open Access Version: <http://kuscholarworks.ku.edu/dspace/>.

Europe Asia Studies, 61(3): 483-504, 2009.

engagement in counterterrorism activities at home and abroad supports what is viewed as NATO and EU counterterrorism efforts, and doing otherwise would constitute a meaningful threat to Estonia's identity as a European democratic nation. Because the adoption of EU and NATO perspectives has occurred at a much deeper level of internalisation of the groups' norms, this study has concluded that Estonia will remain an active participant in peacekeeping and counterterrorism operations, and a generous contributor to development funds, in spite of the lack of a direct contribution of these policies to the republic's security.

\section{References}

Aalto, P. (2003) 'Revisiting the Security/Identity Puzzle in Russo-Estonian Relations', Journal of Peace Research, 40, 5, September.

Adra, A. (2002) British Experts Train the Estonian Specialists in Fighting against Terrorism (Tallinn, Estonian Ministry of the Interior).

Agence France Presse (2005) 'Estonia to Extend Troops Mission in Iraq', 10 November, available at: http://www.lexisnexis.com, accessed 29 December 2008.

Agyeman-Duah, B. \& Olatunde, O.B.J. (1991) 'Interstate Conflicts in West Africa: The Reference Group Theory Perspective', Comparative Political Studies, 24, 3, pp. 299-318.

Amnesty International (2000) 'NATO/Federal Republic of Yugoslavia: "Collateral Damage” or Unlawful Killings? Violations of the Laws of War by NATO during Operation Allied Force', June. AI Index: EUR 70/18/00, available at: http://users.otenet.gr/ nmas/nato_summ.pdf, accessed 29 December 2008.

Appelquist, B. (2003) 'The European Union v. the North Atlantic Treaty Organization: Estonia's Conflicting Interests as a Party to the International Criminal Court', Hastings International and Comparative Law Review, 27, 1, pp. 77-102.

Archick, K. (2005) 'US - EU Cooperation against Terrorism', CRS Report for Congress, RS 22030, 12 June, available at: http://www.fas.org/sgp/crs/terror/ RS22030.pdf, accessed 29 December 2008.

Assembly of Western European Union (2004) 'Security and Defense in Estonia, Latvia and Lithuania', Document A/1861, 2 June, available at: http:/www.assembly-weu.org/en/documents/sessions_ordinaires/rpt/2004/ 1861.html, accessed 29 December 2008. 
Omelicheva, Mariya Y. Reference Group Perspective on State Behavior: A Case Study of Estonia's Counterterrorism Policies, Europe Asia Studies, 61(3): 483-504, 2009. Publisher's Official Version: <http://dx.doi.org/10.1080/09668130902753317>. Open Access Version: <http://kuscholarworks.ku.edu/dspace/>.

Europe Asia Studies, 61(3): 483-504, 2009.

Ayliffe, D.D. (2005) NATO Counterterrorism and Article 5: Hammer of the North Atlantic or Paper Tiger, Working Paper 635, 1 June (Berkeley, CA: bepress Legal Series), available at: http://law.bepress.com/ expresso/eps/635, accessed 29 December 2008.

Baltic News Service (2004a) 'Security Police Say Threat of Terrorism in Estonia is Small. 2004', 24 April, available at: http://www.lexisnexis.com, accessed 13 May 2008.

Baltic News Service (2004b) 'Estonian Foreign Minister: EU Support for Iraq Must Rest on Partnership', 4 September, available at: http://www.lexisnexis.com, accessed 13 May 2008.

Baltic News Service (2005) 'Estonia's Security Risks Must Be Reassessed - Official', 8 July, available at: http://www.lexisnexis.com, accessed 13 May 2008.

Blanton, H. \& Christie, C. (2003) 'Deviance Regulation: A Theory of Action and Identity', Review of General Psychology, 7, 2, pp. 115-49.

Checkel, J. (2005) 'International Institutions and Socialization in Europe: Introduction and Framework', International Organization, 59, 4, October.

Conover, P. (1988) 'The Role of Social Groups in Political Thinking', British Journal of Political Science, 18, 1.

Council of Europe Parliamentary Assembly (2002) 'Risks for the Integrity of the Statute of the International Criminal Court', European Parliament Assembly, $29^{\text {th }}$ Session, RES 1300 (2002), 24 September, available at: http://www.iccnow.org/ documents/EPReportArt98_24Sept02.pdf, accessed 29 December 2008.

Cronin, B. (1999) Community Under Anarchy: Transnational Identity and the Evolution of Cooperation (New York, Columbia University Press).

Easmaa, E. (2005) 'Report of the Foreign Affairs Committee at the Foreign Policy Debate in the Riigikogu', (Tallinn, Estonian Ministry of Foreign Affairs).

Estonian Ministry of Defence (2002) 'Baltic Defence Co-operation', 10 January, available at: http://www.vm.ee/eng/nato/kat_361, accessed 7 November 2007.

Estonian Ministry of Foreign Affairs (2001a) 'Estonia and Common Foreign and Security Policy of the European Union', 16 May, available at: http://www.vm.ee/eng/euro/kat_315/2761.html, accessed 7 November 2007.

Estonian Ministry of Foreign Affairs (2001b) National Security Concept of the Republic of Estonia (Tallinn: Estonian Ministry of Foreign Affairs), available at: http://web-static.vm.ee/static/ failid/335/SecurityConcept.pdf, accessed 29 December 2008. 
Omelicheva, Mariya Y. Reference Group Perspective on State Behavior: A Case Study of Estonia's Counterterrorism Policies, Europe Asia Studies, 61(3): 483-504, 2009. Publisher's Official Version: <http://dx.doi.org/10.1080/09668130902753317>. Open Access Version: <http://kuscholarworks.ku.edu/dspace/>.

Europe Asia Studies, 61(3): 483-504, 2009.

Estonian Ministry of Foreign Affairs (2002a) 'NATO Candidates Meet in Riga', Estonian Defence Digest, 17 July, available at http://www.vm.ee/eng/nato/kat_352/3172.html, accessed 29 December 2008.

Estonian Ministry of Foreign Affairs (2002b) 'Rescue Exercise Completed in Iceland', Estonian Defence Digest, 17 July, available at http://www.vm.ee/eng/ nato/kat_352/3172.html, accessed 29 December 2008.

Estonian Ministry of Foreign Affairs (2003a) Key Activities with NATO (Tallinn, Estonian Ministry of Foreign Affairs).

Estonian Ministry of Foreign Affairs (2003b) Statement of the Vilnius Group Countries (Tallinn, Estonian Ministry of Foreign Affairs).

Estonian Ministry of Foreign Affairs (2005) 'Baltic States Engaged in Major Counter-Terrorism Exercise', Estonian Review, 4 May, available at: http://www.vm.ee/eng/kat_137/5388.html, accessed 29 December 2008.

EU Council (1995) Declaration on Terrorism (La Gomera Declaration). Issued by the Ministers of Home Affairs and Justice, Madrid, 14 October, available at: http://www.europarl.europa.eu/summits/mad2_en.htm\#annex3, accessed 29 December 2008.

EU Council (2004) 'Council of Europe Regulation (EC) No 871/2004 of 29 April 2004 Concerning the Introduction of Some New Functions for the Schengen Information System, in Particular in the Fight against Terrorism', Official Journal of the European Union (OJ L), 162, 30 April.

EU Council (2005) 'The Hague Programme: Strengthening Freedom, Security and Justice in the European Union', Official Journal of the European Union (OJ C), 53, 3 March.

European Commission (2004) 'Eurobarometer 62: Public Opinion in the European Union. National Report. Estonia. Executive Summary', Autumn, available at: http://ec.europa.eu/public_opinion/archives/eb/eb62/ eb62_ee_exec.pdf, accessed 3 July, 2007.

Fearon, J. \& Wendt, A. (2002) 'Rationalism v. Constructivism: A Skeptical View’, in Carlsnaes, W., Risse, T., \& Simmons, B. (eds) (2002) Handbook of International Relations (London, Sage).

Finnemore, M. \& Sikkink, K. (2001) 'Taking Stock: The Constructivist Research Program in International Relations and Comparative Politics', Annual Review of Political Science 4, 3, June.

Gheciu, A. (2005) 'Security Institutions as Agents of Socialization? NATO and the "New Europe", International Organization, 59, 4, October. 
Omelicheva, Mariya Y. Reference Group Perspective on State Behavior: A Case Study of Estonia's Counterterrorism Policies, Europe Asia Studies, 61(3): 483-504, 2009. Publisher's Official Version: <http://dx.doi.org/10.1080/09668130902753317>. Open Access Version: <http://kuscholarworks.ku.edu/dspace/>.

Europe Asia Studies, 61(3): 483-504, 2009.

Herek, G.M. (1986) 'The Instrumentality of Attitudes: Toward a Neofunctional Theory', Journal of Social Issues 42, 2, pp. 99-114.

Human Rights Watch (2006) ‘Afghanistan: NATO Should Do More to Protect Civilians’, 30 October.

Hyman, H.H. (1968) 'Reference Groups', in Sills, D. (ed.) (1968).

Ilves, T.H. (1997) 'Left Out of the Debate about NATO', Washington Post, April 16, A17.

Ilves, T.H. (1999a) 'The Estonian Perspective on EU and NATO Enlargement', presented at the conference 'German and American Policies Towards the Baltic states: The perspectives of EU and NATO Enlargement', Bonn, 7 May, available http://www.vm.ee/eng/kat_140/1223.html?arhiiv_kuup=kuup_1999, accessed 1 April 2008.

Ilves, T.H. (1999b) 'EU Enlargement and Estonia's Identity on the International Stage', presented at the International Conference 'Estonia and the European Union', Tallinn, 5 November, available at: http://www.vm.ee/eng/pressreleases/ speeches/1999/11.05.CFSP.htm, accessed 1 April 2008.

Ilves, T.H. (2001) Main Guidelines of Estonia's Foreign Policy. Address by Minister of Foreign Affairs to the Riigikogu on behalf of the Government of Estonia, 25 October (Tallinn, Estonian Ministry of Foreign Affairs), available at: http://web-test.vm.ee/e\%3Cbr\%3Eg/kat_140/781.html, accessed 29 December 2008.

Ilves, T.H. (2002) 'Eesti heitlus suuremas kaalus', Eesti Päevaleht, 2 November, available at: http://www.epl.ee/?artikkel=219199, accessed 29 December 2008.

Johnson, A. (2005) 'Conclusions and Extensions: Toward Mid-Range Theorizing and Beyond Europe', International Organization, 59, 4, October.

Kelly, H. (1952) ‘Two functions of reference groups', in Swanson, G. at el (eds) (1952).

Kuus, M. (2002) 'European Integration in Identity Narratives in Estonia: A Quest for Security', Journal of Peace Research, 30, 1, January.

Laffan, B. (2004) 'The European Union and Its Institutions as "Identity Builders"', in Herrmann, R., Risse, T., \& Brewer, M. (eds) (2004) Transnational Identities: Becoming European in the EU (Lanham, Rowman \& Littlefield Publishers Inc.).

Lugna, L. (2006) 'Institutional Framework of the European Union Counter-Terrorism Policy Setting', Baltic Security and Defence Review, 8, pp. 101-27. 
Omelicheva, Mariya Y. Reference Group Perspective on State Behavior: A Case Study of Estonia's Counterterrorism Policies, Europe Asia Studies, 61(3): 483-504, 2009. Publisher's Official Version: <http://dx.doi.org/10.1080/09668130902753317>. Open Access Version: <http://kuscholarworks.ku.edu/dspace/>.

Europe Asia Studies, 61(3): 483-504, 2009.

Maccoby, E., Newcomb, T. \& Hartley, E. (eds) (1958) Readings in Social Psychology (New York, Holt, Rinehart \& Winston).

Majone, G. (1991) 'Cross-National Sources of Regulatory Policymaking in Europe and the United States' Journal of Public Policy 11, 1.

Made, V. (2005) Estonia and the Iraqi Crisis (Tallinn, Estonian School of Democracy Publications).

Ministry for Foreign Affairs of Finland (1999) 'EU - US Summit Statement on Chechnya', Press Release 14074/99 (Presse 419), 17 December, available at: http://www.consilium.europa.eu/ueDocs/cms_Data/docs/ pressdata/en/er/14074.EN9.htm, accessed 29 December 2008.

Mooney, C. (2001) 'Modeling Regional Effects on State Policy Diffusion' Political Research Quarterly 54, 1, March.

National Security Concept of the Republic of Estonia (2001). Adopted by Riigikogu Resolution of 16 June 2001 (Tallinn, Estonian Ministry of Foreign Affairs), available at: http://merln.ndu.edu/whitepapers/Estonia2004.pdf, accessed 20 December 2008.

NATO (1991) The Alliance's Strategic Concept, approved in the Meeting of the North Atlantic Council, Rome, 8 November (Brussels, NATO Basic Texts), available at: http://www.nato.int/docu/basictxt/b911108a.htm, accessed 29 December, 2008.

NATO (1999) The Alliance's Strategic Concept, approved in the Meeting of the North Atlantic Council, Washington, D.C., 23-24 April (Brussels, NATO Press Release NAC-S(99)65), available at:http://www.nato.int/docu/pr/1999/p99-065e.htm, accessed 29 December 2008.

NATO (2002a) Prague Summit Declaration 2002 issued by the Heads of State and Government participating in the meeting of NATO in Prague, 21 November (Brussels: NATO Press Release (2002)127), available at: http://www.nato.int/ docu/pr/2002/p02-127e.htm, accessed 29 December 2008.

NATO (2002b) 'Military Concept for Defence against Terrorism', 21 November 2002, available at: http://www.nato.int/ims/docu/terrorism.htm, accessed 7 November 2007.

Newcomb, T. (1958) 'Attitude Development as a Function of Reference Groups: The Bennington study', in Maccoby, E. et al. (1958).

Noreen, E. \& Sjöstedt, R. (2004) 'Estonian Identity Formation and Threat Framing in the Post-Cold War Era', Journal of Peace Research, 51, 6, November. 
Omelicheva, Mariya Y. Reference Group Perspective on State Behavior: A Case Study of Estonia's Counterterrorism Policies, Europe Asia Studies, 61(3): 483-504, 2009. Publisher's Official Version: <http://dx.doi.org/10.1080/09668130902753317>. Open Access Version: <http://kuscholarworks.ku.edu/dspace/>.

Europe Asia Studies, 61(3): 483-504, 2009.

Ojuland, K. (2002) 'Main Guidelines of Estonia's Foreign Policy'. Address by Minister of Foreign Affairs to the Riigikogu on behalf of the Government of the Republic of Estonia, 19 December (Tallinn, Estonian Ministry of Foreign Affairs), available at: http://www.vm.ee/eng/kat_140/3255.html?arhiiv _kuup=kuup_2002, accessed 29 December 2008.

Omelicheva, M. (2007) 'Counterterrorism and Human Rights: Explaining Differences in the Level and Brutality of States' Responses to Terrorism', Ph.D. thesis, Purdue University.

Paet, U. (2005) Address of the Minister of Foreign Affairs of the Republic of Estonia to the Riigikogu on behalf of the Government of Estonia, 20 June (Tallinn, Estonian Ministry of Foreign Affairs), available at: http://www.vm.ee/eng/kat_140/5767.html?arhiiv_kuup=kuup_2005, accessed 29 December 2008.

Paet, U. (2006) Main Guidelines of Estonia's Foreign Policy. Address of the Minister of Foreign Affairs of the Republic of Estonia to the Riigikogu on behalf of the Government of Estonia, 6 June (Tallinn, Estonian Ministry of Foreign Affairs), available at: http://www.vm.ee/eng/kat_140/7567.html, accessed 30 December 2008.

Rees, W. \& Aldrich, R.J. (2005) 'Contending Cultures of Counterterrorism: Transatlantic Divergence or Convergence?', International Affairs, 81, 5, pp. 905-23.

Price, R.M. (1971) 'A Theoretical Approach to Military Rule in New States: Reference-Group Theory and the Ghanaian Case', World Politics 23, 3, pp. 399-430.

Riim, T. (2006) ‘Estonia and NATO: A Constructivist View on a National Interest and Alliance Behaviour', Estonia and NATO-A Constructivist View, 8, pp. 41-52.

Rivera, S.W. (2004) 'Elites and the Diffusion of Foreign Models in Russia', Political Studies 52, 1, pp. 43-62.

Rose, R. (1993) Lesson-Drawing in Public Policy: A Guide to Learning across Time and Space (Chatham, Chatham House).

Security Police Board of Estonia (2007) 'Combating Terrorism', available at: http://www.kapo.ee/eng_terrorism.html, accessed 7 November 2007.

Sills, D. (ed.) (1968) International Encyclopedia of the Social Sciences, Vol. 13 (New York, Macmillan Company \& Free Press).

Spencer, A. (2006) 'Counter-Terrorism in New Europe: What Have the New EU Members Done to Combat Terrorism after September 11 ${ }^{\text {th }}$ ?', International Public Policy Review, 2, 2, pp. 92-112. 
Omelicheva, Mariya Y. Reference Group Perspective on State Behavior: A Case Study of Estonia's Counterterrorism Policies, Europe Asia Studies, 61(3): 483-504, 2009. Publisher's Official Version: <http://dx.doi.org/10.1080/09668130902753317>. Open Access Version: <http://kuscholarworks.ku.edu/dspace/>.

Europe Asia Studies, 61(3): 483-504, 2009.

Swanson, G., Newcomb, T. \& Hartley, E. (eds) (1952) Society for the Psychological Study of Social Issues, Readings in Social Psychology (New York, Holt, Rinehart \& Winston).

Trofimov, A. (1992) 'Russia and the Baltic: How to Continue to Live', Diplomaticheskii Vestnik, 13-14, July.

UN Security Council (2001) Report to the Counter-Terrorism Committee Pursuant to Paragraph 6 of Security Council Resolution 1373 (2001). Estonia. S/2001/1315, 10 January, available at: http://www.un.org/sc/ctc/countryreports/ Creports.shtml, accessed 29 December 2008.

UN Security Council (2002) Supplementary Report for the Counter-Terrorism Committee Regarding the Implementation of Resolution 1373 (2001). Estonia. S/2002/870, 1 August, available at: http://www.un.org/sc/ctc/countryreports/Creports.shtml, accessed 29 December 2008.

UN Security Council (2003) Further Supplementary Report for the Counter-Terrorism Committee Regarding the Measures Taken by Estonia to Implement Resolution 1373 (2001). S/2003/275, 6 March, available at: http://www.un.org/sc/ctc/countryreports/Creports.shtml, accessed 29 December 2008.

UN Security Council (2005) Implementation Measures of UN Security Council Resolution 1373 (2001). S/2005/91.

22 February, available at: http://www.un.org/sc/ctc/countryreports/Creports.shtml, accessed 29 December 2008.

U.S. Department of State. The Bureau of European and Eurasian Affairs (2006) U.S. Government Assistance to Eastern Europe under the Support for East European Democracy (SEED) Act - Fiscal Year 2005. January, available at: http://www.state.gov/p/eur/rls/rpt/c17488.htm, accessed 29 December 2008.

Velliste, T. (1993) Speech of Mr. Trivimi Velliste, Minister of Foreign Affairs of Estonia at the NUPI-CSIS Conference on Baltic and Nordic Security, Oslo, 21 September, available at: http://www.vm.ee/est/kat_140/1376.html, accessed 29 December 2008.

de Vries, G. (2004) 'European Strategy in the Fight against Terrorism and Co-operation with the United States', presented at the Center for Strategic and International Studies European Dialogue Lunch, Washington, D.C., 13 May, available at: http://www.europa-eu-un.org/articles/en/article_3510_en.htm, accessed 29 December 2008.

Weil, F. (1993) 'The Development of Democratic Attitudes in Eastern and Western Germany in a Comparative Perspective', in Weil, F. (ed.) (1993) Research on Democracy and Society: Democratization in Eastern and Western Europe, Vol.1. (Greenwich, JAI Press). 
Omelicheva, Mariya Y. Reference Group Perspective on State Behavior: A Case Study of Estonia's Counterterrorism Policies,

Europe Asia Studies, 61(3): 483-504, 2009. Publisher's Official Version: <http://dx.doi.org/10.1080/09668130902753317>.

Open Access Version: <http://kuscholarworks.ku.edu/dspace/>.

Europe Asia Studies, 61(3): 483-504, 2009.

Wendt, A. (1999) Social Theory of International Politics (Cambridge: Cambridge University Press).

World Federalist Association (2002) 'Campaign for Global Change. EU Message for the U.S.: Stop Blocking the

ICC', 30 September, available at: http://www.iccnow.org/documents/09-30-2002WFA.pdf, accessed 29 December 2008.

Zürn, M. \& Checkel, J. (2005) 'Getting Socialized to Build Bridges: Constructivism and Rationalism, Europe and the Nation State', International Organization, 59, 4, October. 
Omelicheva, Mariya Y. Reference Group Perspective on State Behavior: A Case Study of Estonia's Counterterrorism Policies, Europe Asia Studies, 61(3): 483-504, 2009. Publisher's Official Version: <http://dx.doi.org/10.1080/09668130902753317>.

Open Access Version: <http://kuscholarworks.ku.edu/dspace/>.

Europe Asia Studies, 61(3): 483-504, 2009.

Table 1. Reference Groups.

\begin{tabular}{|c|c|c|c|c|}
\hline $\begin{array}{l}\text { Types of } \\
\text { States' Goals }\end{array}$ & $\begin{array}{l}\text { Types of } \\
\text { Reference } \\
\text { Groups } \\
\end{array}$ & $\begin{array}{l}\text { Mechanisms of } \\
\text { Influence }\end{array}$ & $\begin{array}{l}\text { Outcomes of } \\
\text { Influence }\end{array}$ & $\begin{array}{l}\text { Factors Conditioning } \\
\text { Reference Groups' } \\
\text { Impact }\end{array}$ \\
\hline Utilitarian & Utilitarian & $\begin{array}{l}\text { Rewards and } \\
\text { punishments }\end{array}$ & $\begin{array}{l}\text { Compliance with } \\
\text { or defiance of the } \\
\text { group's interests }\end{array}$ & $\begin{array}{l}\text { Economic and political } \\
\text { resources }\end{array}$ \\
\hline $\begin{array}{l}\text { Value- } \\
\text { Expressive } \\
\text { (Positive Image) }\end{array}$ & Normative & $\begin{array}{l}\text { Acceptance or } \\
\text { rejection }\end{array}$ & $\begin{array}{l}\text { Conformity with } \\
\text { the group's norms, } \\
\text { values, and } \\
\text { perspectives }\end{array}$ & $\begin{array}{l}\text { Affinity toward the group; } \\
\text { Perceived similarity; } \\
\text { Status of the group; } \\
\text { Benefits from being a part } \\
\text { of the group; } \\
\text { Acceptance by the group; } \\
\text { Geographic proximity }\end{array}$ \\
\hline Informational & Comparison & $\begin{array}{l}\text { Providing or } \\
\text { withholding } \\
\text { important } \\
\text { knowledge, } \\
\text { experience, and } \\
\text { expertise }\end{array}$ & $\begin{array}{l}\text { Changes in the } \\
\text { policies in light of } \\
\text { information about } \\
\text { more efficient or } \\
\text { legitimate ways of } \\
\text { achieving the } \\
\text { policy goal }\end{array}$ & $\begin{array}{l}\text { Perceived expertise and } \\
\text { experience of the group; } \\
\text { Perceived similarity; } \\
\text { Geographic proximity }\end{array}$ \\
\hline
\end{tabular}

